\title{
Landfill leachate treatment with a novel process: Anaerobic ammonium oxidation (Anammox) combined with soil infiltration system
}

\author{
Zhu Liang, Junxin Liu* \\ State Key Laboratory of Environmental Aquatic Chemistry, Research Center for Eco-Environmental Science, \\ Chinese Academy of Sciences, Beijing 100085, PR China \\ Received 25 November 2005; received in revised form 24 May 2007; accepted 24 May 2007 \\ Available online 31 May 2007
}

\begin{abstract}
A novel combined process was proposed to treat municipal landfill leachate with high concentrations of ammonium and organics. This process consisted of a partial nitritation reactor (PNR), an anaerobic ammonium oxidation (Anammox) reactor (AR) and two underground soil infiltration systems (USIS-1 and USIS-2). Based on the optimum operating conditions obtained from batch tests of individual unit, the combined process was continuously operated on a bench scale for 166 days. Partial nitritation was performed in a fixed bio-film reactor $(\mathrm{PNR}$, working volume $=12 \mathrm{~L})$. Ammonium nitrogen-loading rate $(\mathrm{Nv})$ and DO were combined to monitor partial nitritation, and at $T=30 \pm 1{ }^{\circ} \mathrm{C}, \mathrm{Nv}=0.27-1.2 \mathrm{~kg} /\left(\mathrm{m}^{3} \cdot \mathrm{d}\right)$, $\mathrm{DO}=0.8-2.3 \mathrm{mg} / \mathrm{L}$, the ratios of nitrite nitrogen $\left(\mathrm{NO}_{2}{ }^{-}-\mathrm{N}\right)$ to ammonium nitrogen $\left(\mathrm{NH}_{4}{ }^{+}-\mathrm{N}\right)$ were successfully kept close to $1.0-1.3$ in the effluent. Nitrate nitrogen $\left(\mathrm{NO}_{3}{ }^{-}-\mathrm{N}\right)$ less than $43 \mathrm{mg} / \mathrm{L}$ was observed. The effluent of PNR was ideally suited as influent of AR. Sixty-nine percent $\mathrm{COD}_{\mathrm{cr}}$ from the raw leachate was degraded in the PNR. Anammox was carried out in a fixed bio-film reactor $(\mathrm{AR}$, working volume $=36 \mathrm{~L})$. At $T=30 \pm 1{ }^{\circ} \mathrm{C}, \mathrm{Nv}=0.06-0.11 \mathrm{~kg} /\left(\mathrm{m}^{3} \cdot \mathrm{d}\right)$, about $60 \% \mathrm{NH}_{4}{ }^{+}-\mathrm{N}$ and $64 \% \mathrm{NO}_{2}{ }^{-}-\mathrm{N}$ in the influent of AR were simultaneously removed. Inhibition of high-strength $\mathrm{NO}_{2}{ }^{-}-\mathrm{N}$ (up to $1011 \mathrm{mg} / \mathrm{L}$ ) should be responsible for the low removal rate of nitrogen. About $35 \%$ aquatic humic substance (AHS) was degraded in the AR. With the same working volume $(200 \mathrm{~L})$, USIS-1 and USIS-2 were alternately performed to treat the effluent from $\mathrm{AR}$ at one cycle of about 30 days. At hydraulic loading rate $(\mathrm{HLR})=0.02-0.04 \mathrm{~m}^{3} / \mathrm{m}^{3} \cdot \mathrm{d}$, pollutant loading rates $(\mathrm{PLR})=\mathrm{NH}_{4}{ }^{+}-\mathrm{N} \leq 14 \mathrm{~g} / \mathrm{m}^{3} \cdot \mathrm{d}$, $\mathrm{TN} \leq 25 \mathrm{~g} / \mathrm{m}^{3} \cdot \mathrm{d}$, and $\mathrm{COD}_{\mathrm{cr}} \leq 13 \mathrm{~g} / \mathrm{m}^{3} \cdot \mathrm{d}$, average removal efficiencies of $88 \% \mathrm{NH}_{4}{ }^{+}-\mathrm{N}, 67 \% \mathrm{TN}$ and $55 \%$ COD $\mathrm{cr}$ were obtained. Overall, raw leachate with 1430-2720 mg NH${ }_{4}{ }^{+}-\mathrm{N} / \mathrm{L}, 1524-2912 \mathrm{mg}$ TN/L and 1165-2599 $\mathrm{mg} \mathrm{COD}_{\mathrm{cr}} / \mathrm{L}$, was treated by the process and the effluent with 22-58 $\mathrm{mg} \mathrm{NH}_{4}{ }^{+}-\mathrm{N} / \mathrm{L}, 108-300 \mathrm{mg} \mathrm{TN} / \mathrm{L}$ and 32-250 $\mathrm{mg} \mathrm{COD}_{\mathrm{cr}} / \mathrm{L}$ was obtained with average removal efficiencies of $97 \% \mathrm{NH}_{4}{ }^{+}-\mathrm{N}, 87 \%$ TN and $89 \% \mathrm{COD}_{\mathrm{cr}}$. The test results indicated that the combined system could work stably over a long period under the operating conditions, and that the process was feasible for the leachate treatment. AR should be the key to the performance of the combined process.
\end{abstract}

(C) 2007 Elsevier B.V. All rights reserved.

Keywords: Municipal landfill leachate; Partial nitritation; Anammox; Underground soil infiltration system

\section{Introduction}

Municipal landfill leachate is one of the types of high-strength wastewater with the greatest environmental impact. This is due to its pollutants: ammonium nitrogen $\left(\mathrm{NH}_{4}{ }^{+}-\mathrm{N}\right)$, biodegradable and refractory organics and heavy metals [1-2]. At present, heavy metals are not at major concern because average metal concentrations are fairly low. Ammonium and organics are the most significant components of leachate for the long term [2-3].

\footnotetext{
* Corresponding author. Tel.: +86 1062849133 ; fax: +86 1062849133.

E-mail address: jxliu@ mail.rcees.ac.cn (J. Liu).
}

Satisfactory treatment of leachate is not an easy task for its high concentrations of ammonium nitrogen and refractory organics. Briefly, leachate can be treated by different methods: biological methods (aerobic, anaerobic) [4-7] and physicochemical methods: precipitation, oxidation, adsorption, stripping, reverse osmosis, etc. [8-10] to remove organic matter and ammonium nitrogen. Due to the operation costs and secondary pollution, physicochemical methods are mainly suitable for pretreatment or post-treatment to complement the biological treatment process [11]. Biological technologies for landfill leachate treatment have been shown to be the economic and effective methods to degrade organic matter and ammonium. No individual technology can guarantee particular treatment efficiencies due to high levels of $\mathrm{NH}_{4}{ }^{+}-\mathrm{N}$ and COD in leachate, 
therefore, combined processes should be adopted to improve treatment performance and to reduce overall running costs.

Conventional biological nitrogen removal process contains two stages: aerobic nitrification of ammonium to nitrate and anoxic denitrification of nitrate to nitrogen gas using readily biodegradable organic matter as electron acceptor. Due to low $\mathrm{C} / \mathrm{N}$ ratio, high ammoniacal-nitrogen and refractory organic matter in landfill leachate, traditional biological technologies have encountered some problems, such as low removal efficiency of total nitrogen (TN), high-energy consumption and unstable running. Reducing oxygen and $\mathrm{C}$-source requirement and enhancing the TN removal efficiency are the keys to the biological processes.

Anammox (anaerobic ammonium oxidation), an autotrophic nitrogen removal method, uses $\mathrm{NH}_{4}{ }^{+}-\mathrm{N}$ as electron donor and nitrite nitrogen $\left(\mathrm{NO}_{2}{ }^{-}-\mathrm{N}\right)$ as electron acceptor to accomplish nitrogen removal (Eq. (1)) [12]. Without the need of organics, this technology has been developed to mainly treat ammonium rich wastewaters, such as landfill leachate, poultry manure and supernatant of digested sludge [13-16].

$$
\begin{aligned}
& \mathrm{NH}_{4}{ }^{+}+1.32 \mathrm{NO}_{2}{ }^{-}+0.066 \mathrm{HCO}_{3}{ }^{-}+0.13 \mathrm{H}^{+} \\
& \rightarrow 0.066 \mathrm{CH}_{2} \mathrm{O}_{0.5} \mathrm{~N}_{0.15}+1.02 \mathrm{~N}_{2}+0.26 \mathrm{NO}_{3}{ }^{-}+2.03 \mathrm{H}_{2} \mathrm{O}
\end{aligned}
$$

Prior to Anammox, partial nitritation (converting part of ammonium to nitrite) should be set in order to produce the appropriate ratio of nitrite/ammonium in the mixture $[17,18]$. Both nitrification stage and ammonium conversion efficiency must be controlled simultaneously in the partial nitritation process. On one hand, the oxidation of nitrite to nitrate must be prevented in order to acquire stable nitrite accumulation; on the other hand, the conversion efficiency of ammonium must be about $57 \%$ theoretically so that the nitrite/ammonium ratio produced is about 1.3. In this way, Anammox combined with partial nitritation (partial nitritation-Anammox), a completely autotrophic nitrogen removal technology is achieved. Compared with the conventional biological treatment technologies, the process may have promising technical and economic advantages for landfill leachate treatment because of less oxygen consumption, no organic source addition and low sludge production $[19,20]$.

Organic materials in landfill leachates are typically volatile fatty acids and humic and fulvic compounds [2]. It is certain that biodegradable organic matters (volatile fatty acids) can be removed by heterotrophic bacteria in the partial nitritation stage, and that another measure must be taken to treat the remaining humic and fulvic compounds (refractory organics). Furthermore, there is a small amount of nitrite remaining in the Anammox effluent. Therefore, the residual refractory organics and nitrite must be effectively removed in another process to meet the safe discharge requirements.

Underground soil infiltration system (USIS) with low construction and operation costs can achieve high purification efficiencies due to the complex interactions of hydraulic and purification processes: filtration, sorption, chemical reactions, biotransformation, predation and plant uptake [21]. Therefore, it is an effective and inexpensive treatment technology, and it can be an alternative technology of advanced treatment for landfill leachate.

Based on the above reviews, a novel integrated process was proposed to treat municipal landfill leachate in this study: partial nitritation-Anammox combined with USIS. In the partial nitritation stage, removal of biodegradable organic matter and acquirement of proper nitrite/ammonium ratio mixture (close to 1.0-1.3) were fulfilled. In the Anammox stage, TN was removed without organic carbon addition. In the USIS, the remaining nitrogen compounds and refractory organics from the Anammox effluent were further removed by the combination of biodegradation, filtration and adsorption.

In spite of much experimental work reported in the literature, a systematic investigation on the operating conditions of partial nitritation-Anammox for landfill leachate treatment and evaluation on the performance of the combined process over a long period are still scarce. Therefore, the three treatment units were operated independently in a batchwise fashion for determining the individual operating conditions. And then these optimum conditions were used to conduct the operations of three units in the combined sequence.

Based on the batch test results, the optimum operating conditions of three units have been acquired [22]. The focuses of this publication were to explore the feasibility of the combined process for the landfill leachate treatment and to evaluate the performance of the novel process for long-term running on a bench scale.

\section{Materials and methods}

\subsection{Landfill leachate}

The landfill leachate in this study was obtained from a municipal solid waste (MSW) sanitation landfill site in Beijing, China. Its $\mathrm{NH}_{4}{ }^{+}-\mathrm{N}$ concentration was high, and $\mathrm{C} / \mathrm{N}$ ratio $\left(\mathrm{COD}_{\mathrm{cr}} / \mathrm{NH}_{4}{ }^{+} \mathrm{N}\right)$ was low (Table 1$)$. The concentrations of heavy metals were fairly low (Table 2 ).

\subsection{Experimental set-up}

This process consisted of three major parts: a partial nitritation reactor $(\mathrm{PNR})$, an Anammox reactor (AR) and two

Table 1

Characteristics of investigated leachate

\begin{tabular}{llllll}
\hline Parameter & $\mathrm{NH}_{4}{ }^{+}-\mathrm{N}(\mathrm{mg} / \mathrm{L})$ & $\mathrm{TN}(\mathrm{mg} / \mathrm{L})$ & $\mathrm{COD}_{\mathrm{cr}}(\mathrm{mg} / \mathrm{L})$ & $\left.\mathrm{Alkalinity}_{\left(\mathrm{Na}_{2} \mathrm{CO}\right.}\right)(\mathrm{mg} / \mathrm{L})$ & $\mathrm{pH}$ \\
\hline Range & $1400-2800$ & $1500-3000$ & $1100-2600$ & $8000-15000$ & $8.1-9$ \\
Average \pm S.D. & $1972 \pm 408.2$ & $2117 \pm 426.0$ & $1703 \pm 393.5$ & $11898 \pm 2639$ & $8.5 \pm 0.3$ \\
\hline
\end{tabular}


Table 2

Average concentrations of metals in raw landfill leachate

\begin{tabular}{|c|c|c|c|c|c|c|c|c|c|}
\hline Parameter & $\mathrm{Na}$ & $\mathrm{K}$ & & $\mathrm{Ca}$ & $\mathrm{Mg}$ & $\mathrm{Fe}$ & $\mathrm{Mn}$ & $\mathrm{Ba}$ & $\mathrm{Al}$ \\
\hline Value (mg/L) & 2450.6 & 1881.6 & & 7.23 & 625.8 & 0.95 & 0.01 & 0.06 & 0.38 \\
\hline Parameter & $\mathrm{Cd}$ & & $\mathrm{Cr}$ & & $\mathrm{Cu}$ & $\mathrm{Pb}$ & & $\mathrm{Zn}$ & $\mathrm{Ni}$ \\
\hline Value (mg/L) & 0.006 & & 0.12 & & 0.02 & 0.01 & & 0.02 & 0.2 \\
\hline
\end{tabular}

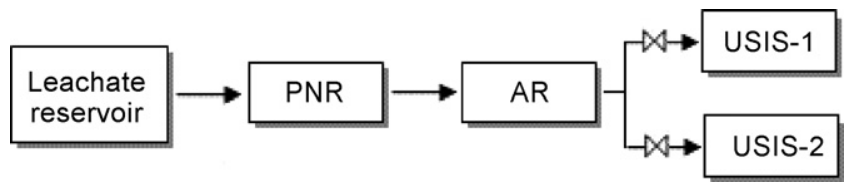

Fig. 1. The flow chart of the combined process.

underground soil infiltration systems (USIS-1 and USIS-2) for trade off. In the combined sequential treatment, the raw landfill leachate was first fed to the PNR for pretreatment. The effluent from that unit was then treated for nitrogen removal in the AR. Finally the Anammox effluent was fed to USIS for advanced treatment. The flow chart and experimental schematic diagram are shown in Figs. 1 and 2, respectively. After the star-up period, continuous running of the whole combined process was begun under the operating conditions from batch tests (Table 3).

\subsubsection{Partial nitritation system and operative scheme}

PNR was a bench scale up-flow fixed bed bio-film reactor with working volume of $12 \mathrm{~L}$ Modified polypropylene balls $(30 \mathrm{~mm} \times 30 \mathrm{~mm})$ were used as carriers with total sur-



Fig. 2. Schematic diagram of the treatment process. 1, PNR; 2, AR; 3, USIS; 4 , metering pump; 5 , air pump; 6 , flowmeter; 7 , heater; 8 , DO meter; 9 , online control $\mathrm{pH}$ meter; 10, dosing device of $\mathrm{NaHCO}_{3}$ or $\mathrm{HCl}$; 11, ORP meter; 12 , metering pump; 13 , water seal; 14 , collection of gas.

Table 3

Operating conditions of three units in the continuous running of combined process

\begin{tabular}{ll}
\hline PNR & Nv: gradually increased from 0.27 to $1.2 \mathrm{~kg} \mathrm{H}{ }^{+}-\mathrm{N} /\left(\mathrm{m}^{3} \cdot \mathrm{d}\right)$ \\
& DO: gradually increased from 0.8 to $2.3 \mathrm{mg} / \mathrm{L}$ \\
& T: $30 \pm 1{ }^{\circ} \mathrm{C}$ \\
AR & Nv: changed along with the effluent from PNR \\
& T: $30 \pm 1^{\circ} \mathrm{C}$ \\
& pH: $7.5-8.0$ \\
USIS & Hydraulic loading rate: $0.02-0.04 \mathrm{~m}^{3} /\left(\mathrm{m}^{3} \cdot \mathrm{d}\right)$ \\
\hline
\end{tabular}

face areas of $4.12 \mathrm{~m}^{2}$. The desired dissolved oxygen (DO) concentration was acquired by adjusting the airflow. The desired ammonium nitrogen-loading rate (Nv) was acquired by adjusting the influent flow. Temperature in the reactor was maintained at $30 \pm 1{ }^{\circ} \mathrm{C}$ by heater. The start-up of reactor is shown in Table 4. The aerobic activated sludge from a landfill leachate plant was used as inoculum $(19 \mathrm{~g}$ MLVSS).

\subsubsection{Anammox system and operative scheme}

AR was a bench scale up-flow fixed bed biofilm reactor with working volume of $36 \mathrm{~L}$. Modified polypropylene balls $(30 \mathrm{~mm} \times 30 \mathrm{~mm})$ were used as carriers with total surface areas of $11.3 \mathrm{~m}^{2}$. The desired $\mathrm{Nv}$ was acquired by adjusting the influent flow. Temperature in the reactor was maintained at $30 \pm 1{ }^{\circ} \mathrm{C}$ by heater. Online $\mathrm{pH}$ control meter with dosing device of chemicals was used to control the $\mathrm{pH}$ value at the range of 7.5-8.0. A novel culture method combining aerobic and subsequent anaerobic culture was used for the AR start-up in order to improve the culture of Anammox bacteria and accelerate start-up. Namely, nitritation biofilm was aerobically cultured in the AR in the first stage with aerobic activated sludge as inoculum (57 g MLVSS), and then anaerobic domestication of Anammox microorganism was begun in the second stage (Table 5).

After 37-day aerobic culture, removal efficiency of ammonium in the influent was more than $90 \%$, and $90 \%$ removed ammonium was converted into nitrite in the PNR and AR. Here, cultures of nitritation biofilm were accomplished in the AR and $\mathrm{PNR}$, and the anaerobic culture in the AR was subsequently begun. After 60-day anaerobic culture, Anammox performance of AR was gradually improved and stable nitrogen removal was acquired with the average removal efficiencies of $67 \% \mathrm{NH}_{4}{ }^{+}-\mathrm{N}$ and $77 \% \mathrm{NO}_{2}{ }^{-}-\mathrm{N}$. Total duration of start-up in the AR was 97 days.

\subsubsection{USIS system and operative scheme}

According to soil column test results in batch tests (not shown here), the feasible operational conditions (hydraulic loading rate and contaminant loading rate) and operational mode had been obtained. The operational mode was: two soil infiltration systems ran alternately to treat the effluent of AR, and one cycle was about 30 days. In the present study, these operational mode and conditions were used to conduct the continuous running of USIS. The USIS, working volume of $200 \mathrm{~L}$, was filled with sandy loam soil. USIS-1 and USIS-2 were fed for trade off with 30-day cycle. 
Table 4

Conditions of acclimation and culture of PNR

\begin{tabular}{|c|c|c|c|}
\hline \multirow[t]{2}{*}{ Duration (days) } & \multicolumn{3}{|l|}{ Conditions } \\
\hline & $\mathrm{DO}(\mathrm{mg} / \mathrm{L})$ & $\mathrm{T}\left({ }^{\circ} \mathrm{C}\right)$ & Wastewater \\
\hline 7 & 2 & $30 \pm 1$ & Mixture of leachate and domestic sewage $(0.4-0.8, \mathrm{v} / \mathrm{v})$ \\
\hline 30 & $1.0-1.5$ & $30 \pm 1$ & $\begin{array}{l}\text { Raw leachate } \\
\mathrm{NH}_{4}{ }^{+}-\mathrm{N}: 1800-2700 \mathrm{mg} / \mathrm{L} ; \mathrm{Nv} \leq 0.8 \mathrm{~kg} \mathrm{NH}_{4}{ }^{+}-\mathrm{N} /\left(\mathrm{m}^{3} \cdot \mathrm{d}\right)\end{array}$ \\
\hline
\end{tabular}

\subsection{Analytic methods}

The concentrations of $\mathrm{NH}_{4}{ }^{+}-\mathrm{N}, \mathrm{NO}_{2}{ }^{-}-\mathrm{N}, \mathrm{NO}_{3}{ }^{-}-\mathrm{N}$, and $\mathrm{TN}$ were determined according to the standard methods issued by the Environmental Protection Agency (EPA) of China. $\mathrm{COD}_{\mathrm{cr}}$ measurement was based on digestion with potassium dichromate in concentrated sulphuric acid using a COD analyzer (CTL-12, China). TOC was measured using a TOC analyzer (Phoenix 8000, Tekmar Dohrmann, USA). Aquatic humic substance (AHS) was analyzed according to APHA (1992) (Method $5510 \mathrm{C}, 996)$ using XAD-7 resin (Rohmhaas, USA) [23]. Temperature and DO were online monitored by a DO meter (Oxi 330i WTW, Germany). The $\mathrm{pH}$ value was determined using glass electrodes connected to a $\mathrm{pH}$ meter (320-S, China). TSS was analyzed by drying the sample at $105^{\circ} \mathrm{C}$ for at least $24 \mathrm{~h}$. After burned at $600^{\circ} \mathrm{C}$ for $1 \mathrm{~h}$, the ash was measured. The difference between TSS and ash was termed as VSS. An ICP-OES analyzer (Perkin-Elmer Optima 2000DV, USA) was used for analyzing metals.

To determine the performance of nitrite build-up and inhibition of nitrate production in the PNR, percentage of nitrite accumulation (PNC) was brought forward in the study, which was calculated according to the Eq. (2).

$\mathrm{PNC}=\frac{C_{\mathrm{NO}_{2}{ }^{-}-\mathrm{N} . \mathrm{eff}}}{C_{\mathrm{NO}_{2}{ }^{-}-\mathrm{N} . \mathrm{eff}}+C_{\mathrm{NO}_{3}{ }^{-}-\mathrm{N} . \mathrm{eff}}} \times 100 \%$

where $C_{\mathrm{NO}_{2}{ }^{-}-\mathrm{N} \text {.eff }}$ and $C_{\mathrm{NO}_{3}{ }^{-}-\text {N.eff }}$ represented the concentrations of $\mathrm{NO}_{2}{ }^{-}-\mathrm{N}$ and $\mathrm{NO}_{3}{ }^{-}-\mathrm{N}$ in the effluent from PNR, respectively.

\section{Results and discussion}

\subsection{Partial nitritation}

Both DO and Nv were the key factors affecting partial nitritation [22]. In the study, their interaction impacts on the partial nitritation were investigated in a 166-day continuous running at $30 \pm 1{ }^{\circ} \mathrm{C}$. As shown in Fig. 3 ( $\mathrm{a}$ and b), along with the increase of $\mathrm{Nv}$ (from 0.27 to $1.2 \mathrm{~kg} \mathrm{NH}_{4}{ }^{+}-\mathrm{N} / \mathrm{m}^{3} \cdot \mathrm{d}$ ), DO was adjusted from 0.8 to $2.3 \mathrm{mg} / \mathrm{L}$. At the beginning of the change of $\mathrm{Nv}$ and $\mathrm{DO}$, the running of PNR fluctuated, and after about 1 week, a stable treatment was achieved again. The raw leachate with $\mathrm{NH}_{4}{ }^{+}-\mathrm{N}$ of $1400-2800 \mathrm{mg} / \mathrm{L}$ was treated, and the effluent with $506-885 \mathrm{mg}$ $\mathrm{NH}_{4}{ }^{+}-\mathrm{N} / \mathrm{L}$ and $438-1011 \mathrm{mg} \mathrm{NO}{ }^{-}{ }^{-} \mathrm{N} / \mathrm{L}$ was acquired. Nitrite oxidation was successfully inhibited and produced $\mathrm{NO}_{3}{ }^{-}-\mathrm{N}$ in the effluent was below $43 \mathrm{mg} / \mathrm{L}$. Ammonium oxidation rate (AOR) increased with the $\mathrm{Nv}$ and was up to maximum $(0.79 \mathrm{~kg}$ $\mathrm{NH}_{4}{ }^{+}-\mathrm{N} / \mathrm{m}^{3} \cdot \mathrm{d}$ ), indicating that ammonium oxidation was not inhibited under the operating conditions. According to Fig. 3(c), percentages of nitrite accumulation were more than $95 \%$, and ammonium removal efficiencies varied from 54 to $73 \%$. Ratios of $\mathrm{NO}_{2}{ }^{-}{ }^{-} \mathrm{N} / \mathrm{NH}_{4}{ }^{+}-\mathrm{N}$ in the effluent varied from 0.56 to 1.26 and almost $80 \%$ ratios were close to $1.0-1.3$. Relatively low ratios were produced at the times of adjustment of $\mathrm{Nv}$ and DO, especially at $t=142$ days, when $\mathrm{Nv}$ was rapidly elevated from 0.68 to $0.83 \mathrm{~kg} \mathrm{NH}_{4}{ }^{+}-\mathrm{N} / \mathrm{m}^{3} \cdot \mathrm{d}$, ammonium removal efficiency fell sharply, from 68 to $54 \%$, resulting in the decrease of the ratio from 0.93 to 0.56 . These results indicated that both nitrite build-up and ammonium removal efficiency were controlled simultaneously to obtain satisfying partial nitritation under applied conditions. Therefore, Nv and DO could be combined to control the partial nitritation for leachate treatment.

Stable nitrogen loss occurred in the PNR with average TN removal efficiency of 30\% (Fig. 4), which resulted from the simultaneous nitritation and denitrification (SND) via nitrite

Table 5

Conditions of acclimation and culture of AR

\begin{tabular}{|c|c|c|c|c|}
\hline \multirow[t]{2}{*}{ Stage } & \multirow[t]{2}{*}{ Duration (days) } & \multicolumn{3}{|l|}{ Conditions } \\
\hline & & $\mathrm{DO}(\mathrm{mg} / \mathrm{L})$ & $T\left({ }^{\circ} \mathrm{C}\right)$ & Wastewater \\
\hline Aerobic & $\begin{array}{r}7 \\
30\end{array}$ & $\begin{array}{l}2 \\
1.0-1.5\end{array}$ & $\begin{array}{l}30 \pm 1 \\
30 \pm 1\end{array}$ & $\begin{array}{l}\text { Mixture of leachate and domestic sewage }(0.4-0.8 \mathrm{v} / \mathrm{v}) \\
\text { Raw leachate } \\
\mathrm{NH}_{4}^{+}-\mathrm{N}: 1800-2700 \mathrm{mg} / \mathrm{L} ; \mathrm{Nv} \leq 0.8 \mathrm{~kg} \mathrm{NH}_{4}^{+}-\mathrm{N} /\left(\mathrm{m}^{3} \cdot \mathrm{d}\right)\end{array}$ \\
\hline Anaerobic & 60 & - & $30 \pm 1$ & $\begin{array}{l}\text { Mixture of the effluent from PNR and tap water } \\
\mathrm{NO}_{2}{ }^{-}-\mathrm{N} / \mathrm{NH}_{4}{ }^{+}-\mathrm{N} \text { ratio: } 1-1.2 \\
\mathrm{NH}_{4}{ }^{+}-\mathrm{N}: 220-480 \mathrm{mg} / \mathrm{L} \\
\mathrm{Nv}: 0.02-0.06 \mathrm{~kg} \mathrm{NH}{ }^{+}-\mathrm{N} /\left(\mathrm{m}^{3} \cdot \mathrm{d}\right)\end{array}$ \\
\hline
\end{tabular}





Fig. 3. Control results of partial nitritation in the PNR using Nv and DO (R represents removal efficiency) (ם, $\mathrm{NH}_{4}{ }^{+}-\mathrm{N}(\mathrm{in}) ; \square, \mathrm{NH}_{4}{ }^{+}-\mathrm{N}\left(\right.$ eff);,$+ \mathrm{NO}_{2}{ }^{-}-\mathrm{N}(\mathrm{eff})$; $\bigcirc, \mathrm{NO}_{3}{ }^{-}-\mathrm{N}(\mathrm{eff}) ; \mathbf{\Lambda}$, ratio; $\left.\oplus, \mathrm{R} ;-, \mathrm{PNC}\right)$.

at limited DO concentration [24]. SND resulted in a decrease of the $\mathrm{NO}_{2}{ }^{-}-\mathrm{N} / \mathrm{NH}_{4}{ }^{+}-\mathrm{N}$ ratio because of the consumption of part nitrite, therefore, actual $\mathrm{NH}_{4}{ }^{+}-\mathrm{N}$ removal efficiency should be more than its theoretical value (57\%) in order to acquire favorite ratio of nitrite/ammonium mixture that will be fed into the following AR. In fact, the favorite ratios (close to

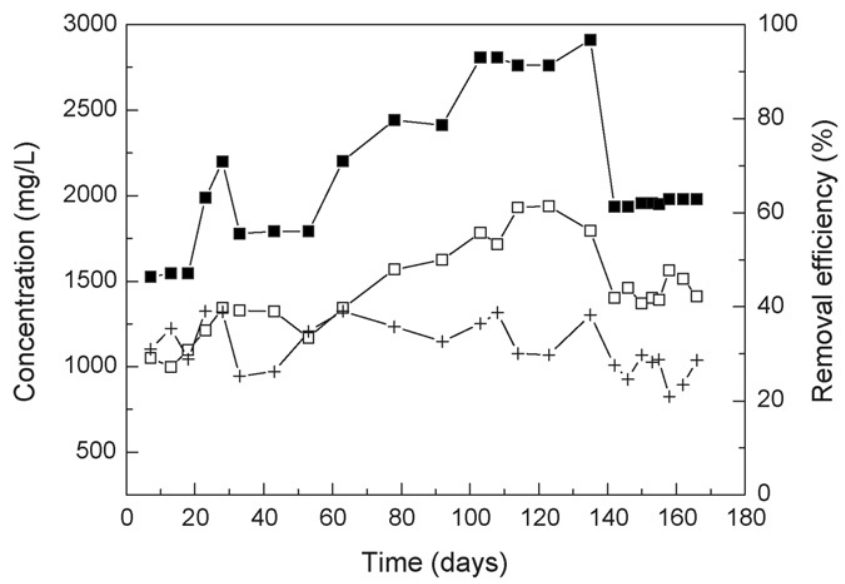

Fig. 4. Nitrogen loss in the PNR (ם, TN(in); $\square, \mathrm{TN}(\mathrm{eff}) ;+, \mathrm{R}(\mathrm{TN}))$.

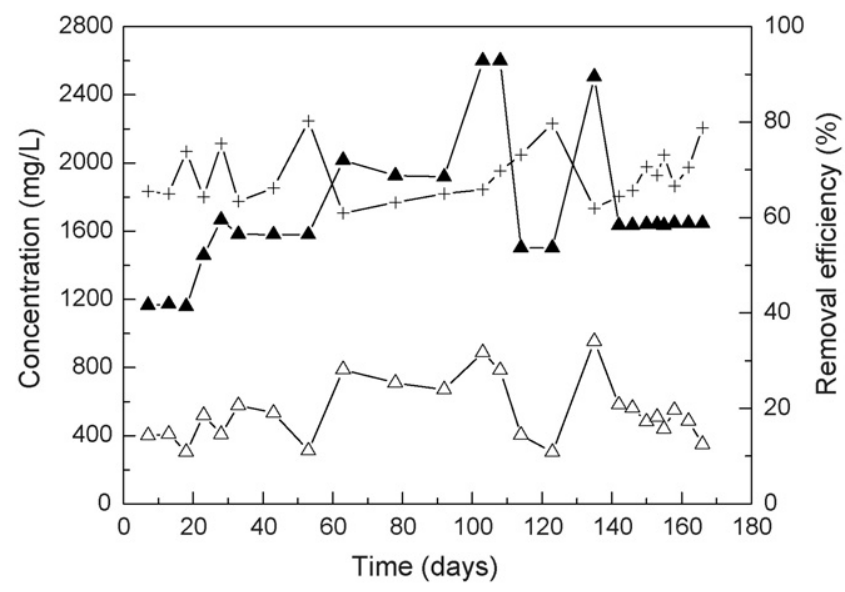

Fig. 5. Removal of $\mathrm{COD}_{\mathrm{cr}}$ in the PNR $\left(\boldsymbol{\Lambda}, \mathrm{COD}_{\mathrm{cr}}(\right.$ in $) ; \triangle, \mathrm{COD}_{\mathrm{cr}}($ eff $) ;+$ $\left.\mathrm{R}\left(\mathrm{COD}_{\mathrm{cr}}\right)\right)$.

$1.0-1.3)$ were produced only when ammonium removal efficiencies were more than $60 \%$ (Fig. 3(c)). A substantial biological degradation of $\mathrm{COD}_{\mathrm{cr}}$ also occurred with $60-81 \%$ removal efficiencies (Fig. 5), which resulted from biological oxidation of heterotrophic bacteria and C-resource consumption in denitrification. Biodegradable organic matter was removed and the residue was mainly fulvic-like organic matter.

Free ammonium (FA) and free nitrous acid (FNA) rather than ammonium and nitrite inhibit nitrifying bacteria, and the toxicities of FA and FNA depend on the environmental $\mathrm{pH}$ at certain temperature [25]. In this study, average alkalinity $\left(\mathrm{Na}_{2} \mathrm{CO}_{3}\right)$ in the influent was $11898 \mathrm{mg} / \mathrm{L}$, and all $\mathrm{pH}$ values in the effluent were all above 8.5 (its average value was 8.6). According to the average $\mathrm{pH}$ value, calculated values of FA and FNA were $160-260 \mathrm{mg} / \mathrm{L}$ and $0.007-0.019 \mathrm{mg} / \mathrm{L}$, respectively [25]. More than $10-150 \mathrm{mg} / \mathrm{L}$ of FA will inhibit oxidation of ammonium and bring about failure of nitrite build-up [25]. However, in this study, the long-term stable partial nitritation was achieved at such high FA level. It was evident that oxidation of nitrite was inhibited, but oxidation of ammonium was not inhibited. It was in accordance with the observation of Princic et al., which reported that nitrifier strains adapted to high ammonium concentration (up to $3000 \mathrm{mg} / \mathrm{L}$ ) at $\mathrm{pH}$ of 8.2 [26]. Owing to the high $\mathrm{pH}$, FNA concentration was so low that its inhibition was ignored.

\subsection{Anammox}

According to the conclusions from batch tests of individual Anammox reactor (not shown here), Nv had been an important factor to influence the stable nitrogen removal, and $\mathrm{Nv}$ above $0.12 \mathrm{~kg} /\left(\mathrm{m}^{3} \cdot \mathrm{d}\right)$ had resulted in the decline of nitrogen removal rate. In the present study, $\mathrm{Nv}$ in the AR was changed along with the effluent quality from PNR and gradually increased from 0.06 to $0.16 \mathrm{~kg} /\left(\mathrm{m}^{3} \cdot \mathrm{d}\right)$ (Fig. $\left.6(\mathrm{a})\right)$. Removal rates of both $\mathrm{NH}_{4}{ }^{+}-$ $\mathrm{N}$ and $\mathrm{NO}_{2}{ }^{-}-\mathrm{N}$ were basically improved with the increase of $\mathrm{Nv}$ before $t=158$ days, thereafter, elevation of $\mathrm{Nv}$ from 0.11 to $0.16 \mathrm{~kg} /\left(\mathrm{m}^{3} \cdot \mathrm{d}\right)$, resulted in an obvious fall of $\mathrm{NH}_{4}{ }^{+}-\mathrm{N}$ removal rate from 0.07 to $0.065 \mathrm{~kg} /\left(\mathrm{m}^{3} \cdot \mathrm{d}\right)$ and a slight variation of $\mathrm{NO}_{2}{ }^{-}$$\mathrm{N}$ removal rate from 0.084 to $0.082 \mathrm{~kg} /\left(\mathrm{m}^{3} \cdot \mathrm{d}\right)$. At $t=166$ day, 

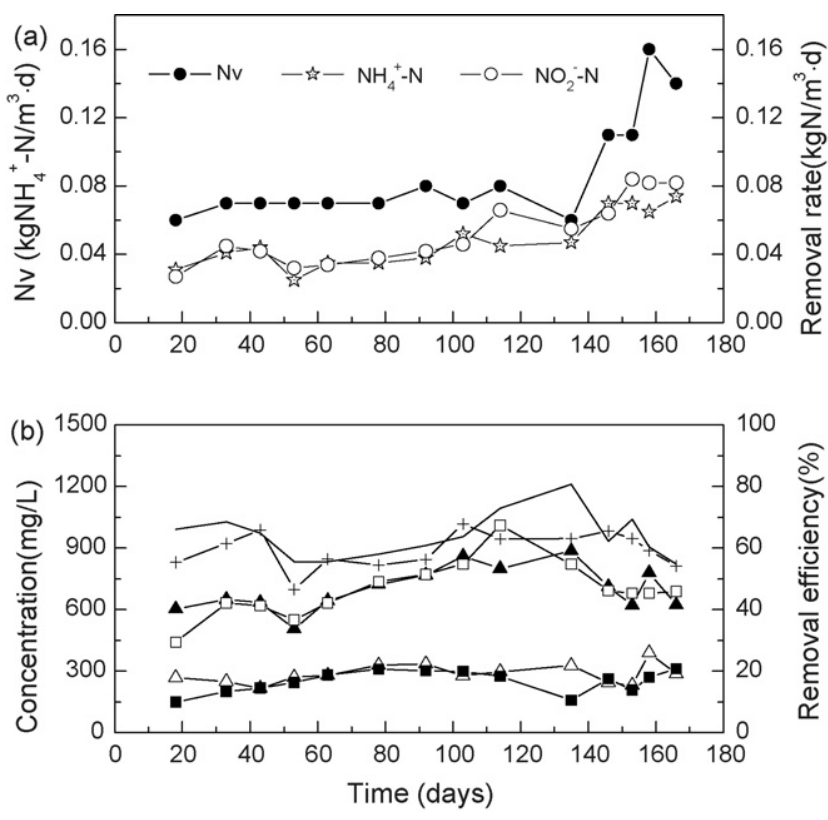

Fig. 6. Effects of $\mathrm{Nv}$ on the removals of $\mathrm{NH}_{4}{ }^{+}-\mathrm{N}$ and $\mathrm{NO}_{2}{ }^{-}-\mathrm{N}$ in the $\mathrm{AR}$ $\left(\boldsymbol{\Lambda}, \mathrm{NH}_{4}{ }^{+}-\mathrm{N}(\mathrm{in}) ; \triangle, \mathrm{NH}_{4}{ }^{+}-\mathrm{N}(\mathrm{eff}) ;+, \mathrm{R}\left(\mathrm{NH}_{4}{ }^{+}-\mathrm{N}\right) ; \square, \mathrm{NO}_{2}{ }^{-}-\mathrm{N}(\mathrm{in}) ; \boldsymbol{\square}, \mathrm{NO}_{2}{ }^{-}\right.$$\left.\mathrm{N}(\mathrm{eff}) ;-, \mathrm{R}\left(\mathrm{NO}_{2}{ }^{-}-\mathrm{N}\right)\right)$.

removal rate of $\mathrm{NH}_{4}{ }^{+}-\mathrm{N}$ rose to $0.074 \mathrm{~kg} /\left(\mathrm{m}^{3} \cdot \mathrm{d}\right)$ with the reduction of Nv. As illustrated in Fig. 6(b), 506-885 $\mathrm{mg} \mathrm{NH}_{4}{ }^{+}-\mathrm{N} / \mathrm{L}$ and $441-1011 \mathrm{mg} \mathrm{NO}_{2}{ }^{-} \mathrm{-N} / \mathrm{L}$ from the effluent of PNR were continuously fed into the AR, and the AR effectively treated them to acquire the effluent with $216-388 \mathrm{mg} \mathrm{NH}_{4}{ }^{+}-\mathrm{N} / \mathrm{L}$ and $149-311 \mathrm{mg} \mathrm{NO}_{2}{ }^{-}-\mathrm{N} / \mathrm{L}$.

Overall, both removal rate and removal efficiency of $\mathrm{NH}_{4}{ }^{+}-$ $\mathrm{N}$ were less than those of $\mathrm{NO}_{2}{ }^{-}-\mathrm{N}$ during the whole running period. Average removal rates of $\mathrm{NH}_{4}{ }^{+}-\mathrm{N}$ and $\mathrm{NO}_{2}{ }^{-}-\mathrm{N}$ were 0.049 and $0.053 \mathrm{~kg} /\left(\mathrm{m}^{3} \cdot \mathrm{d}\right)$, respectively. Average removal efficiencies of $\mathrm{NH}_{4}{ }^{+}-\mathrm{N}$ and $\mathrm{NO}_{2}{ }^{-}-\mathrm{N}$ were 60 and $64 \%$, respectively. Moreover, it seemed that the increase of $\mathrm{Nv}$ had greater impact on the removal of $\mathrm{NH}_{4}{ }^{+}-\mathrm{N}$ than on that of $\mathrm{NO}_{2}{ }^{-}-\mathrm{N}$. These results were all consistent with those in batch tests.

In Anammox process, a small quantity of $\mathrm{NO}_{2}{ }^{-}-\mathrm{N}$ is converted to $\mathrm{NO}_{3}{ }^{-}-\mathrm{N}$ to meet the possible need for electrons to reduce $\mathrm{CO}_{2}$ for autotrophic growth, and produced $\mathrm{NO}_{3}{ }^{-} \mathrm{-N}$ accounts for about $10 \%$ of the N-feed [27]. Fig. 7 demonstrates that nitrate was also produced in this study; however, its production was relatively low. Concentration of $\mathrm{NO}_{3}{ }^{-}-\mathrm{N}$ was changed from 1.2 to $73 \mathrm{mg} / \mathrm{L}$ with average value of $29.3 \mathrm{mg} / \mathrm{L}$, which averagely accounted for $3.2 \%$ of the converted nitrogen. The average ammonium and nitrite degradation and the nitrate production yielded a ratio of 1:1.09:0.07 and was less than the stoichiometric ratio given in Eq. (1) (1:1.32:0.26).

Fig. 8 shows the removal of $\mathrm{TN}$ in the AR, indicating that removal rate had growth with the $\mathrm{Nv}$ and also had a fall at $t=158$ days. Average removal rate was $0.11 \mathrm{~kg} /\left(\mathrm{m}^{3} \cdot \mathrm{d}\right)$.

Because autotrophic Anammox bacteria have relatively slow growth rate, the substrates and other compounds in the raw wastewater have possible toxicities to Anammox activity. Anammox process is not inhibited by $\mathrm{NH}_{4}{ }^{+}-\mathrm{N}$ or $\mathrm{NO}_{3}{ }^{-}-\mathrm{N}$ up to concentrations of at least $1000 \mathrm{mg} / \mathrm{L}$; however, $\mathrm{NO}_{2}{ }^{-}-\mathrm{N}$ of more

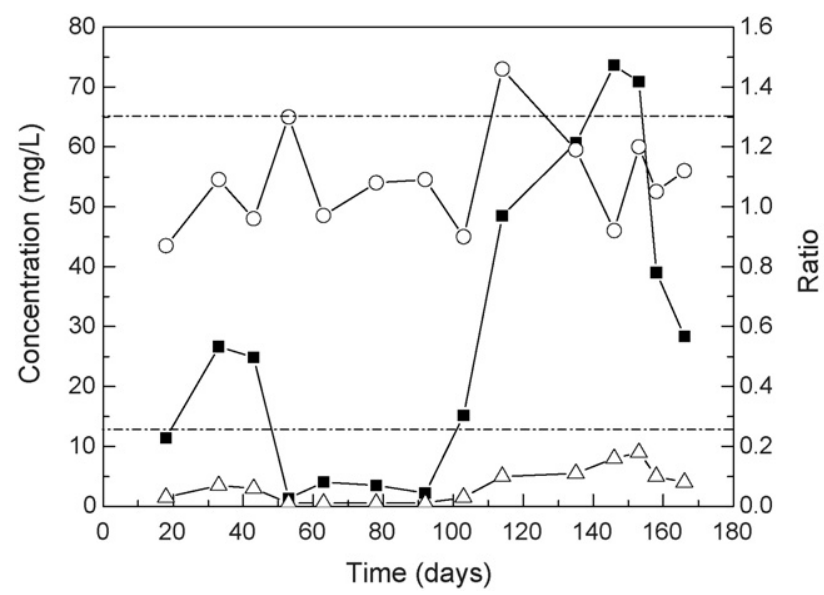

Fig. 7. Ratios of ammonium and nitrite degradation and the nitrate production $\left(\boldsymbol{\square}, \mathrm{NO}_{3}{ }^{-}-\mathrm{N}(\right.$ eff $) ; \bigcirc$, ratio of removed $\mathrm{NO}_{2}{ }^{-}-\mathrm{N}$ to removed $\mathrm{NH}_{4}{ }^{+}-\mathrm{N} ; \Delta$, ratio of produced $\mathrm{NO}_{3}{ }^{-}-\mathrm{N}$ to removed $\mathrm{NH}_{4}{ }^{+}-\mathrm{N}$ ).

than $100 \mathrm{mg} / \mathrm{L}$ can completely inhibit the process [28]; at concentrations of nitrite more than $18 \mathrm{mM}$ the Anammox activity is completely inhibited [14]; $25 \mathrm{mM}$ nitrite corresponds to the $50 \%$ inhibition concentration and $50 \mathrm{mM}$ acetate results in $70 \%$ inhibition percentage [29]; phosphate $(5-50 \mathrm{mM})$ has strong inhibition of Anammox activity, and $50 \mathrm{mM} \mathrm{KCl}$ or $40 \mathrm{mM}$ $\mathrm{KHCO}_{3}$ has no effect on Anammox [27]; low oxygen concentrations have reversible inhibition of Anammox, but higher oxygen concentrations have irreversible inhibition (18\% of oxygen saturation) [14]; $2 \mathrm{mM}$ sulfide and $1 \mathrm{mM}$ sulfite have active effect [27]. From these results, it has been suggested that nitrite exerts the highest inhibitory effect on the activity of Anammox microorganisms, and the nitrite concentration in an Anammox reactor must be strictly controlled to avoid inhibition of the process [29].

Based on the above literature, the following analyses suggested that nitrite made greatest adverse effect on the Anammox process in this study: (1) average concentration of $\mathrm{NO}_{2}{ }^{-}-\mathrm{N}$ in the influent of AR was $698 \mathrm{mg} / \mathrm{L}$, and sometimes it was as high as $1011 \mathrm{mg} / \mathrm{L}$; (2) fulvic-like compound was the main organic matter in the influent of AR, which should have little adverseness to Anammox activity; (3) alkalinity $\left(\mathrm{Na}_{2} \mathrm{CO}_{3}\right)$ in the raw leachate

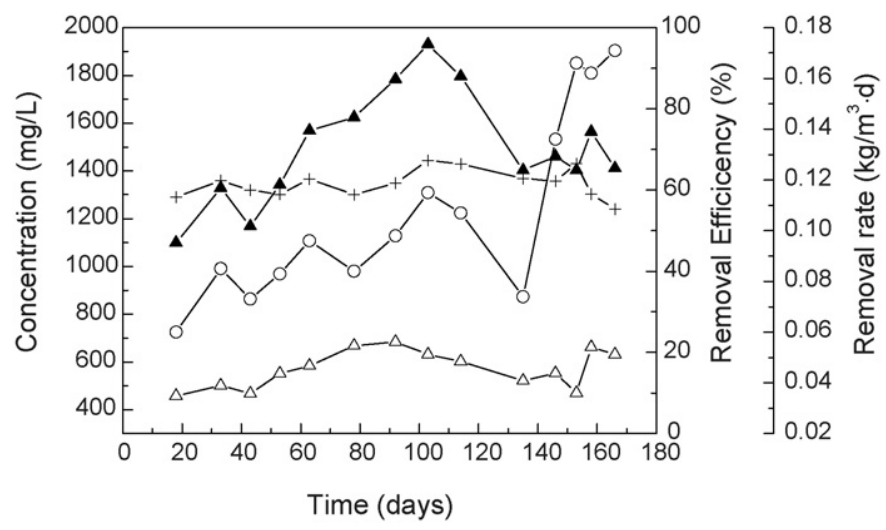

Fig. 8. Removal of $\mathrm{TN}$ in the $\mathrm{AR}(\boldsymbol{\Lambda}, \mathrm{TN}(\mathrm{in}) ; \triangle, \mathrm{TN}(\mathrm{eff}) ;+, \mathrm{R}(\mathrm{TN}) ; \bigcirc$, removal rate). 




Fig. 9. Removal of $\mathrm{COD}_{\mathrm{cr}}$ in the $\mathrm{AR}\left(\square, \mathrm{COD}_{\mathrm{cr}}(\mathrm{in})\right.$; $\mathbf{\square}, \mathrm{COD}_{\mathrm{cr}}(\mathrm{eff})$; ,$\left.+ \mathrm{R}\left(\mathrm{COD}_{\mathrm{cr}}\right)\right)$.

was consumed a lot in the PNR, and the remaining $\mathrm{Na}_{2} \mathrm{CO}_{3}$ should be inorganic C-resource of Anammox microorganism; (4) the AR was fully airproofed to maintain the anaerobic condition; (5) concentration of phosphate in the leachate was fairly low; (6) concentrations of heavy metals in the raw leachate were so low as to have little inhibitions.

Anammox process is used to treat synthetic wastewater with $70-840 \mathrm{mg} \mathrm{NH}_{4}{ }^{+}-\mathrm{N} / \mathrm{L}$ and $70-840 \mathrm{mg} \mathrm{NO}_{2}{ }^{-}-\mathrm{N} / \mathrm{L}$, and maximum nitrogen conversion capacity $\left(0.7 \mathrm{~kg} \mathrm{NH}_{4}{ }^{+}-\mathrm{N} /\left(\mathrm{m}^{3} \cdot \mathrm{d}\right)\right.$ and $\left.1.5 \mathrm{~kg} \mathrm{TN} /\left(\mathrm{m}^{3} \cdot \mathrm{d}\right)\right)$ is obtained [30]. In an Anammox fluidized bed reactor at maximum loading rate of $0.43 \mathrm{~kg} \mathrm{NH}_{4}{ }^{+} \mathrm{N} /\left(\mathrm{m}^{3} \cdot \mathrm{d}\right)$, influent with $267 \mathrm{mg} \mathrm{NH}_{4}{ }^{-}$-N/L and $227 \mathrm{mg} \mathrm{NO}_{2}{ }^{-}-\mathrm{N} / \mathrm{L}$ is treated, and about $0.33 \mathrm{~kg} \mathrm{NH}{ }^{+}-\mathrm{N} /\left(\mathrm{m}^{3} \cdot \mathrm{d}\right)$ removal rate is acquired [31]. Compared with these results, both loading rate and removal rate of nitrogen in the AR were relatively low in this study. That high-strength nitrite made great inhibition of Anammox activity should be the main reason.

No matter how much $\mathrm{COD}_{\mathrm{cr}}$ was in the influent of $\mathrm{AR}$ (from 303 to $954 \mathrm{mg} / \mathrm{L}$ ), part of $\mathrm{COD}_{\text {cr }}$ was removed with removal efficiencies of $23-41 \%$ during the 166-day operating period (Fig. 9).
Furthermore, $\mathrm{COD}_{\mathrm{cr}}$ removal seemed to have no correlation with the nitrogen removal and variation of Nv. There was no doubt that almost all biodegradable organics could be degraded in the PNR, and that there should be only refractory organics like fulvic compound remaining in the effluent. Therefore, it could be inferred that removed organics in the AR should mainly be fulvic-like material. Because fulvic-like material is aquatic humic substance (AHS) [32], it can be determined by means of the analysis of AHS. Because the analysis of AHS was timeconsuming, only six sets of samples were analyzed. Six sets of data were ranked according to the concentration (Fig. 10(a)). As illustrated in Fig. 10(a and b), both AHS and TOC in the effluent from PNR always were partly removed in the AR with average removal efficiencies of 35 and $36 \%$, respectively, which suggested that the removed AHS was certainly mineralized, if not, TOC could not simultaneously removed. Furthermore, the percentages of the AHS removed/the TOC removed were all above $75 \%$ (Fig. 10(c)), suggesting that the removed TOC was mainly AHS in the AR.

Denitrifier could not directly use fulvic-like material for denitrification, and Anammox microorganism, autotrophic bacterium, did not need it. Therefore, other microorganism might biodegrade it. There were two possible mechanisms for the mineralization of fulvic-like material: (1) it was directly mineralized by some kinds of heterotrophs; (2) it was firstly degraded into readily biodegradable organic matter by some kinds of heterotrophs, and then was utilized by denitrifier. According to the nitrogen removal (Figs. 6 and 7), average removed $\mathrm{NO}_{2}{ }^{-}-\mathrm{N}$ was $449.3 \mathrm{mg} / \mathrm{L}$; average removed $\mathrm{NH}_{4}{ }^{+}-\mathrm{N}$ was $414.7 \mathrm{mg} / \mathrm{L}$ and average produced $\mathrm{NO}_{3}{ }^{-}-\mathrm{N}$ was $29.3 \mathrm{mg} / \mathrm{L}$. $\mathrm{NH}_{4}{ }^{+}-\mathrm{N}$ removal was certainly ascribed to Anammox, which needed $414.7 \mathrm{mg}$ $\mathrm{NO}_{2}{ }^{-} \mathrm{N} / \mathrm{L}$ as electron receiver and converted $29.3 \mathrm{NO}_{2}{ }^{-}-$ $\mathrm{N} \mathrm{mg} / \mathrm{L}$ into $\mathrm{NO}_{3}{ }^{-}-\mathrm{N}$. Therefore, only $5.3 \mathrm{mg} \mathrm{NO}_{2}{ }^{-}-\mathrm{N} / \mathrm{L}$ was possibly denitrified (needing $9.1 \mathrm{mg} / \mathrm{L} \mathrm{C}$-resource), which accounted for $1.2 \%$ of total removed $\mathrm{NO}_{2}{ }^{-} \mathrm{N}$. Based on the average TN removal efficiency of $62 \%$ (Fig. 8) and average $\mathrm{NH}_{4}{ }^{+}-\mathrm{N}$ removal efficiency of $60 \%$ (Fig. 6), it could be inferred that the removed TN ascribed to Anammox accounted for $97 \%$.
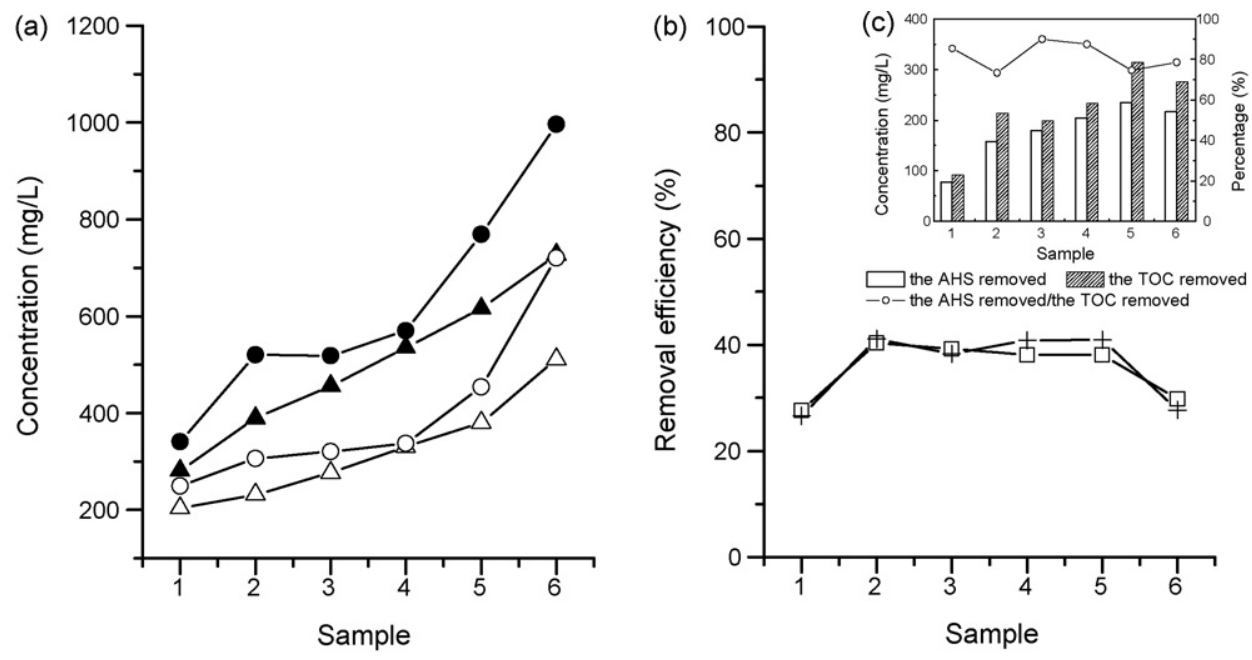

Fig. 10. Removals of AHS and TOC in the AR ( $\mathbf{\Lambda}$, AHS(in); $\triangle$, AHS(eff);

, TOC(in); $\bigcirc$, TOC(eff); $\square, \mathrm{R}(\mathrm{AHS}) ;+, \mathrm{R}(\mathrm{TOC}))$ 
These results implied that Anammox was dominant over denitrification for the nitrogen removal in the AR, and that organic matter consumed for denitrification was in a quite small quantity. Therefore, the AHS removal should be ascribed to the first possible mechanism.

\subsection{USIS}

According to batch tests of soil column (not shown here), hydraulic loading rate (HLR) and pollutant loading rate (PLR) were important factors influencing performance of soil treatment system. Relatively high loading rates could not maintain stable running for the long term; relatively low loading rates would demand much soil. The feasible HLR was below $0.05 \mathrm{~m}^{3} /\left(\mathrm{m}^{3} \cdot \mathrm{d}\right)$ $(3.2 \mathrm{~cm} / \mathrm{d})$ and PLRs were as follows: $\mathrm{NH}_{4}{ }^{+}-\mathrm{N} \leq 9.9 \mathrm{~g} /\left(\mathrm{m}^{3} \cdot \mathrm{d}\right)$, $\mathrm{TN} \leq 21 \mathrm{~g} /\left(\mathrm{m}^{3} \cdot \mathrm{d}\right)$, and $\mathrm{COD}_{\mathrm{cr}} \leq 9.9 \mathrm{~g} /\left(\mathrm{m}^{3} \cdot \mathrm{d}\right)$. The operational mode was that two soil infiltration systems ran alternately to treat the effluent of AR, and the cycle was 1 month. In this study, these operational conditions and operational mode were applied and verified in the 166-day continuous running.

During the whole running period (Fig. 11), both USIS-1 and USIS-2 ran two cycles. In the first cycle, HLR was maintained at $0.02 \mathrm{~m}^{3} /\left(\mathrm{m}^{3} \cdot \mathrm{d}\right)$, and PLRs varied with the effluent quality from the AR: (1) the loading rates of both $\mathrm{NH}_{4}{ }^{+}-\mathrm{N}$ and TN were relatively steady, and were about 5.0 and $9.5 \mathrm{~g} /\left(\mathrm{m}^{3} \cdot \mathrm{d}\right)$, respectively; (2) the $\mathrm{COD}_{\mathrm{cr}}$ loading rate varied at $3.4-9.8 \mathrm{~g} /\left(\mathrm{m}^{3} \cdot \mathrm{d}\right)$. In the second cycle, HLR increased gradually from 0.2 to $0.4 \mathrm{~m}^{3} /\left(\mathrm{m}^{3} \cdot \mathrm{d}\right)$; the loading rates of both $\mathrm{NH}_{4}{ }^{+}-\mathrm{N}$ and $\mathrm{TN}$ were gradually elevated from 4.5 and 9.1 to 14.0 and $24.8 \mathrm{~g} /\left(\mathrm{m}^{3} \cdot \mathrm{d}\right)$, respectively,

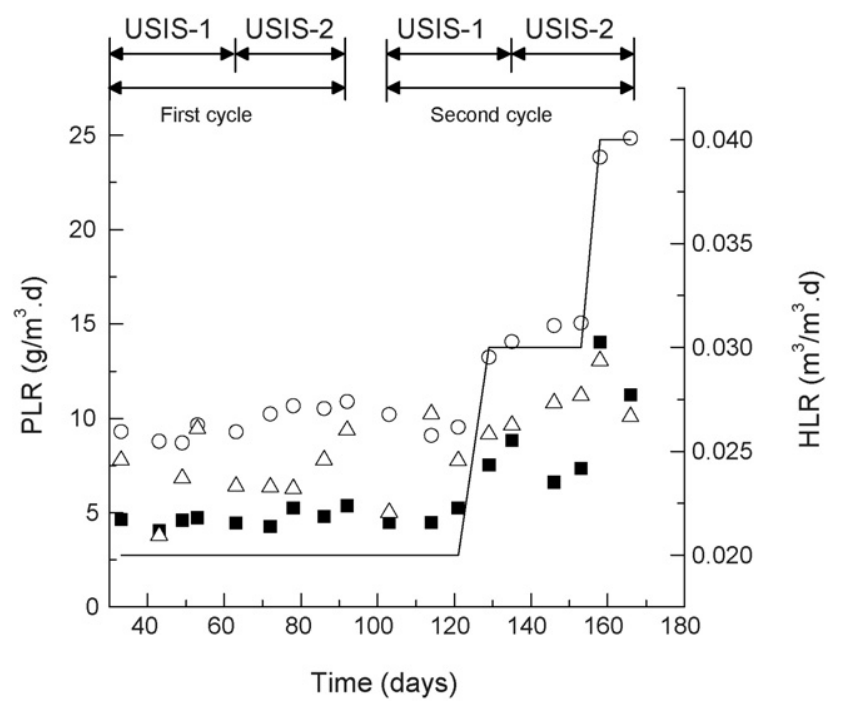

Fig. 11. HLR and PLR in the USIS during the running period $\left(\mathbf{\square}, \mathrm{NH}_{4}{ }^{+}-\mathrm{N} ; \bigcirc\right.$ $\mathrm{TN} ; \triangle$, CODcr; -, HLR).

the $\mathrm{COD}_{\mathrm{cr}}$ loading rate varied at $5-13 \mathrm{~g} /\left(\mathrm{m}^{3} \cdot \mathrm{d}\right)$. According to Fig. 12(a and b), during the two cycles, the removals of $\mathrm{NH}_{4}{ }^{+}-\mathrm{N}$ and $\mathrm{NO}_{2}{ }^{-}-\mathrm{N}$ were quite steady with high removal efficiencies, and $\mathrm{NH}_{4}{ }^{+}-\mathrm{N}$ and $\mathrm{NO}_{2}{ }^{-}-\mathrm{N}$ in the effluent were averagely 32 and $3.9 \mathrm{mg} / \mathrm{L}$ with average removal efficiencies of 88 and $98 \%$, respectively. However, the treatment capabilities for TN and $\mathrm{COD}_{\mathrm{cr}}$ were weakened in the second cycle. Average concentration of $\mathrm{TN}$ in the effluent increased from $176 \mathrm{mg} / \mathrm{L}$ in the first cycle to $211 \mathrm{mg} / \mathrm{L}$ in the second cycle; average concentra-
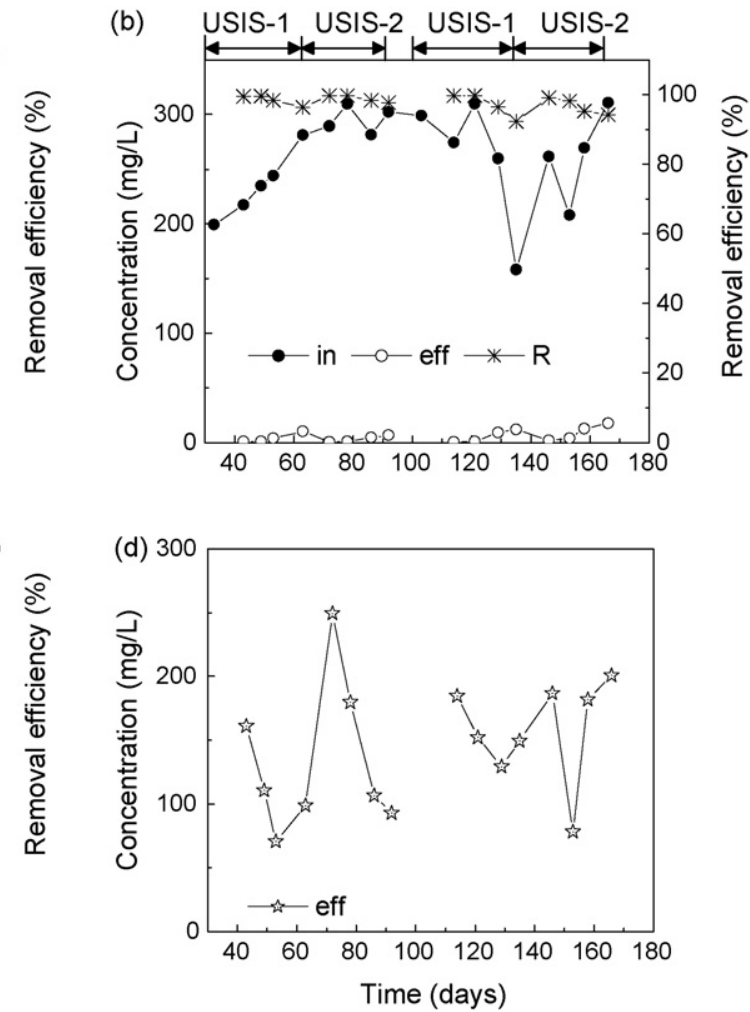

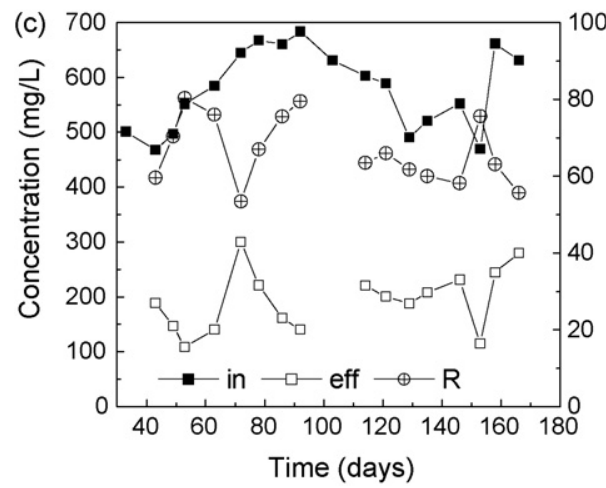

Fig. 12. Variation of nitrogen in the effluent of USIS. (a) $\mathrm{NH}_{4}{ }^{+}-\mathrm{N}$; (b) $\mathrm{NO}_{2}{ }^{-}-\mathrm{N}$; (c) $\mathrm{TN}$; (d) $\mathrm{NO}_{3}{ }^{-}-\mathrm{N}$ ). 
Table 6

Average removal efficiencies of landfill leachate by the combined process

\begin{tabular}{llll}
\hline Reactor & Removal efficiency & & \multicolumn{1}{c}{$\begin{array}{c}\text { Percentage of nitrite } \\
\text { accumulation }(\%)\end{array}$} \\
\cline { 2 - 4 } & $\mathrm{NH}_{4}{ }^{+}-\mathrm{N} \%$ & $\mathrm{TN} \%$ & $\mathrm{COD}_{\mathrm{cr}} \%$ \\
\hline PNR & 64 & 30 & 69 \\
AR & 60 & 62 & 32 \\
USIS & 88 & 67 & 55 \\
Combined process & 97 & 87 & 89 \\
\hline
\end{tabular}

tion of $\mathrm{COD}_{\mathrm{cr}}$ in the effluent increased from $174 \mathrm{mg} / \mathrm{L}$ in the first cycle to $194 \mathrm{mg} / \mathrm{L}$ in the second cycle (Figs. 12(c) and 13). The increases of HLR and PLR in the second cycle should be the main reasons, and the results were consistent with those in batch tests, indicating that feasible operating conditions obtained from soil column tests should be followed. These results also suggested that the increases of HLR and PLR had obviously negative influences on the removals of TN and $\mathrm{COD}_{\mathrm{cr}}$ and had little influences on the removals of $\mathrm{NH}_{4}{ }^{+}-\mathrm{N}$ and $\mathrm{NO}_{2}{ }^{-}-\mathrm{N}$. Therefore, the removals of $\mathrm{TN}$ and $\mathrm{COD}_{\mathrm{cr}}$ seemed to be the keys to the USIS. Almost all $\mathrm{NO}_{2}{ }^{-}-\mathrm{N}$ from the AR effluent was removed and converted to $\mathrm{NO}_{3}{ }^{-}-\mathrm{N}$ to obtain safe discharge (Fig. 12(d)). However, denitrification of $\mathrm{NO}_{3}{ }^{-}-\mathrm{N}$ was limited because of the insufficiency of biodegradable C-resource, resulting in relatively low removal efficiency of TN.

After being fed, soil firstly adsorbed refractory organic matter, and then adsorbed organic matter was gradually converted into low-molecular-weight matter by microorganism, which was easily utilized by denitrifier and other heterotrophs; therefore, removal efficiency of $\mathrm{COD}_{\mathrm{cr}}$ always gradually decreased because of adsorption saturation. Herein, after being fed for 30 days, one USIS stopped running, and then adsorbed refractory organic matter was degraded in another 30 days in order to acquire the resume of adsorption capability. As shown in Fig. 13, removal efficiency of $\mathrm{COD}_{\mathrm{cr}}$ in USIS- 1 was about $50 \%$ at the end of the first cycle ( $t=63$ days), and after 30-day rest, it was

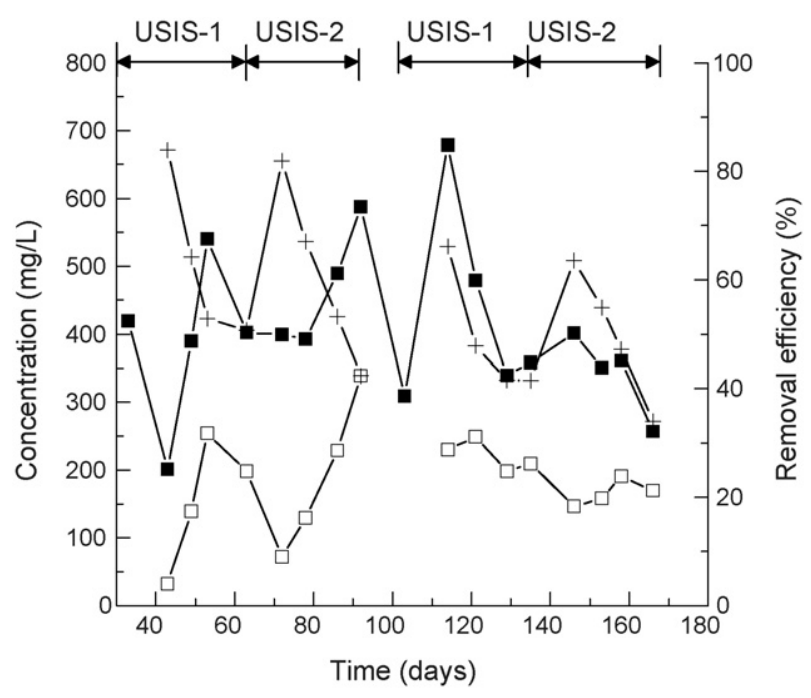

Fig. 13. Removal of $\mathrm{COD}_{\text {cr }}$ in the USIS ( $\mathbf{\square}$, in; $\square$, eff; +, R). resumed to $66 \%$ at the beginning of the second cycle $(t=114$ days); removal efficiency in USIS- 2 was $42 \%$ at the end of the first cycle ( $t=92$ days), and after 30-day rest, it was resumed to $64 \%$ at the beginning of the second cycle ( $t=146$ days).

\subsection{Treatment for leachate by the combined process}

Treatment results of the combined process for landfill leachate are listed in Table 6. About $86 \% \mathrm{NH}_{4}{ }^{-}-\mathrm{N}, 73 \% \mathrm{TN}$ and $79 \% \mathrm{COD}_{\mathrm{cr}}$ in landfill leachate were removed in partial nitritation-Anammox process, and the purification of the remaining pollutants was accredited to the USIS. Overall, the raw leachate with 1430-2720 $\mathrm{mg} \mathrm{NH}_{4}{ }^{+}-\mathrm{N} / \mathrm{L}, 1524-2912 \mathrm{mg} \mathrm{TN} / \mathrm{L}$ and $1165-2599 \mathrm{mg} \mathrm{COD}$ cr $/ \mathrm{L}$ was treated by the combined system, and the effluent with $22-58 \mathrm{mg} \mathrm{NH}{ }_{4}{ }^{+} \mathrm{N} / \mathrm{L}, 108-300 \mathrm{mg}$ $\mathrm{TN} / \mathrm{L}$ and $32-250 \mathrm{mg} \mathrm{COD} \mathrm{Cr}_{\mathrm{cr}} / \mathrm{L}$ was obtained. Average removal efficiencies were $97 \% \mathrm{NH}_{4}{ }^{+}-\mathrm{N}, 87 \% \mathrm{TN}$ and $89 \% \mathrm{COD}_{\mathrm{cr}}$. Effective treatment for the landfill leachate was accomplished.

The test results showed that the advisable operating conditions could ensure stable work of the system over a long period. Certainly, these conditions would be expected to vary with leachates of different landfill sites and different ages. Compared with the other processes, the system offered effective removals of high concentrations of ammonium and organics with relatively low energy consumption, however, removals of TN and $\mathrm{COD}_{\mathrm{cr}}$ should be improved. Therefore, further studies should be made for full-scale implementation of the combined process.

\section{Conclusions}

The municipal landfill leachate obtained from an old-aged landfill site was treated using a combined process including partial nitritation-Anammox and underground soil infiltration system. The test results from 166-day continuous running revealed the following information.

(1) Under the conditions of this study, it was possible to operate the combined process on a long-term basis and to accomplish the effective treatment for the leachate. Average removal efficiencies with $97 \% \mathrm{NH}_{4}{ }^{+}-\mathrm{N}, 87 \% \mathrm{TN}$ and $89 \% \mathrm{COD}_{\mathrm{cr}}$ were obtained.

(2) Ammonium loading rate and DO were excellent parameters for monitoring partial nitritation. An anticipant of nitrite/ammonium ratio close to $1.0-1.3$ in the effluent could 
be acquired by controlling them. Ammonium oxidizing bacteria in the PNR seemed to be acclimated to high FA level of $160-260 \mathrm{mg} / \mathrm{L}$ so that nitritation was not inhibited.

(3) About $60 \% \mathrm{NH}_{4}^{+}-\mathrm{N}$ and $64 \% \mathrm{NO}_{2}{ }^{-}-\mathrm{N}$ were simultaneously removed in the AR. Although denitrification might occur in the AR, 97\% of the removed TN was ascribed to Anammox. Nv up to $0.16 \mathrm{~kg} /\left(\mathrm{m}^{3} \cdot \mathrm{d}\right)$ could result in obvious fall of nitrogen removal rate. Inhibition of high-strength $\mathrm{NO}_{2}{ }^{-} \mathrm{N}$ (as high as $1011 \mathrm{mg} / \mathrm{L}$ ) should be responsible for the relatively low removal rate of nitrogen. It was interesting that average 35\% removal efficiency of AHS was obtained in the AR.

(4) Two soil infiltration systems ran alternately to treat the effluent of AR, and one cycle was about 30 days. On an average, $88 \% \mathrm{NH}_{4}{ }^{-} \mathrm{N}$ and $98 \% \mathrm{NO}_{2}{ }^{-}-\mathrm{N}$ in the effluent from $\mathrm{AR}$ were converted into $\mathrm{NO}_{3}{ }^{-}-\mathrm{N}$ in the USIS, and safe discharge was acquired. Increases of HLR and PLR exerted more influence on the removals of $\mathrm{TN}$ and $\mathrm{COD}_{\mathrm{cr}}$ than on those of $\mathrm{NH}_{4}{ }^{+}-\mathrm{N}$ and $\mathrm{NO}_{2}{ }^{-}-\mathrm{N}$, indicating that removals of $\mathrm{TN}$ and $\mathrm{COD}_{\mathrm{cr}}$ were the key in the USIS.

(5) Of the three units, AR should be the key to the performance of the combined process. For the purpose of full-scale application of the integrated process, two major issues remained to be solved in the further studies: how to reduce inhibition of high-concentration $\mathrm{NO}_{2}{ }^{-}-\mathrm{N}$ to Anammox microorganism and how to improve the loading rate and removal rate in the AR.

\section{Acknowledgements}

The authors are grateful to the financial support from the National Natural Science Foundation of China (No. 50238050) and the National Hi-Tech Development Plan (863 Plan) in China (No. 2002AA649250).

\section{References}

[1] M. Irene, C. Lo, Characteristics and treatment of leachates from domestic landfills, Environ. Int. 22 (1996) 433-442.

[2] P. Kjeldsen, M.A. Barlaz, A.P. Rooker, A. Baun, A. Ledin, T.H. Christensen, Present and long-term composition of MSW landfill leachate: a review, Crit. Rev. Environ. Sci. Technol. 32 (2002) 297-336.

[3] T.H. Christensen, P. Kjeldsen, P.L. Bjerg, D.L. Jensen, J.B. Christensen, A. Baun, H.J. Albrechtsen, G. Heron, Biogeochemistry of landfill leachate plumes, Appl. Geochem. 16 (2001) 659-718.

[4] J.H. Im, H.J. Woo, M.W. Choi, K.B. Han, C.W. Kim, Simultaneous organic and nitrogen removal from municipal landfill leachate using an anaerobicaerobic system, Water Res. 35 (2001) 2403-2410.

[5] J.P.Y. Jokela, R.H. Kettunen, K.M. Sormunen, J.A. Rintala, Biological nitrogen removal from municipal landfill leachate: low-cost nitrification in biofilters and laboratory scale in situ denitrification, Water Res. 36 (2002) 4079-4087.

[6] O.N. Agdag, D.T. Sponza, Anaerobic/aerobic treatment of municipal landfill leachate in sequential two-stage up-flow anaerobic sludge blanket reactor (UASB)/completely stirred tank reactor (CSTR) systems, Process Biochem. 40 (2005) 895-902.

[7] N. Laitinen, A. Luonsi, J. Vilen, Landfill leachate treatment with sequencing batch reactor and membrane bioreactor, Desalination 191 (2006) 8691.
[8] X.Z. Li, Q.L. Zhao, X.D. Hao, Ammonium removal from landfill leachate by chemical precipitation, Waste Manage. 19 (1999) 409415.

[9] S.H. Lin, C.C. Chang, Treatment of landfill leachate by combined electroFenton oxidation and sequencing batch reactor method, Water Res. 34 (2000) 4243-4249.

[10] D. Trebouet, J.P. Schlumpf, P. Jaquen, F. Quemeneur, Stabilized landfill leachate treatment by combined physicochemical-nanofiltration processes, Water Res. 35 (2001) 2935-2942.

[11] T.A. Kurniawan, Wai-hung Lo, G.Y.S. Chan, Physic-chemical treatments for removal of recalcitrant contaminants from landfill leachate, J. Hazard. Mater. B129 (2006) 80-100.

[12] M. Strous, J.J. Heijnen, J.G. Kuenen, M.S.M. Jetten, The sequencing batch reactor as a powerful tool for the study of slowly growing anaerobic ammonium-oxidizing microorganisms, Appl. Microbiol. Biotechnol. 50 (1998) 589-596.

[13] H. Siegrist, S. Reithaar, G. Koch, P. Lais, Nitrogen loss in a nitrifying rotating contactor treating ammonium-rich wastewater without organic carbon, Water Sci. Technol. 38 (1998) 241-248.

[14] K. Egli, U. Fanger, P.J.J. Alvarez, H. Siegrist, J.R. van der Meer, A.J.B. Zehnder, Enrichment and characterization of an anammox bacterium from a rotating biological contactor treating ammonium-rich leachate, Arch. Microbiol. 175 (2001) 198-207.

[15] X. Dong, E.W. Tollner, Evaluation of Anammox and denitrification during anaerobic digestion of poultry manure, Bioresour. Technol. 86 (2003) 139-145.

[16] C. Fux, M. Boehler, P. Huber, I. Brunner, H. Siegrist, Biological treatment of ammonium-rich wastewater by partial nitritation and subsequent anaerobic ammonium oxidation (anammox) in a pilot plant, J. Biotechnol. 99 (2002) 295-306.

[17] Y.H. Ahn, Sustainable nitrogen elimination biotechnologies: a review, Process Biochem. 41 (2006) 1709-1721.

[18] L. Gut, E. Płaza, B. Hultman, Assessment of a two-step partial nitritation/Anammox system with implementation of multivariate data analysis, Chemom. Intell. Lab. Syst. 86 (2007) 26-34.

[19] I. Schmidt, O. Sliekers, M. Schmid, E. Bock, J. Fuerst, J.G. Kuenen, M.S.M. Jetten, M. Strous, New concepts of microbial treatment processes for the nitrogen removal in wastewater, FEMS Microbiol. Rev. 772 (2003) 112.

[20] T. Khin, A.P. Annachhatre, Novel microbial nitrogen removal processes, Biotechnol. Adv. 22 (2004) 519-532.

[21] S. Vancuyk, R. Siegrist, A. Logan, S. Masson, E. Fischer, L. Figueroa, Hydraulic and purification behaviors and their interactions during wastewater treatment in soil infiltration systems, Water Res. 35 (2001) 953964.

[22] Z. Liang, J.X. Liu, Control factors of partial nitritation for landfill leachate treatment, J. Environ. Sci. 19 (2007) 523-529.

[23] B.U. Bae, E.S. Jung, Y.R. Kim, H.S. Shin, Treatment of landfill leachate using activated sludge process and electron-beam radiation, Water Res. 33 (1999) 2669-2673.

[24] H. Christine, K. Sabine, Simultaneous nitrification/denitrification in an aerobic biofilm system, Water Sci. Technol. 37 (1998) 183187

[25] A.C. Anthoniesm, R.C. Loehr, T.S. Prakasam, Inhibition of nitrification by ammonia and nitrous acid, J. Water Pollut. Control. Fed. 48 (1976) 835-852.

[26] A. Princic, I. Mahne, F. Megusar, E.A. Paul, J.M. Tiedje, Effects of pH and oxygen and ammonium concentrations on the community structure of nitrifying bacteria from wastewater, Appl. Environ. Microbiol. 64 (1998) 3584-3590.

[27] A.A. van de Graaf, P. de Bruijn, L.A. Robertson, Autotrophic growth of anaerobic ammonium-oxidizing microorganisms in a fluidized bed reactor, Microbiology 142 (1996) 2187-2196.

[28] M. Strous, J.G. Kuenen, M.S.M. Jetten, Key physiology of anaerobic ammonium oxidization, Appl. Environ. Microbiol. 65 (1999) 32483250 .

[29] A.D. Mora, I. Fernandez, J.L. Campos, A.M. Corral, R. Mendez, M.S.M. Jetten, Evaluation of activity and inhibition effects on Anammox process by 
batch tests based on the nitrogen gas production, Enzyme Microb. Technol. 40 (2007) 859-865.

[30] M. Strous, E. van Gerven, P. Zheng, J.G. Kuenen, M.S.M. Jetten, Ammonium removal from concentrated wastewater streams with anaerobic ammonium oxidation (Anammox) process in different reactor configurations, Water Res. 31 (1997) 1955-1962.
[31] M.S.M. Jetten, S.J. Horn, M.C.M. van Loosdrecht, Towards a more sustainable muinicipal wastewater treatment system, Water Sci. Technol. 35 (1997) 171-180.

[32] E.S.K. Chian, F.B. DeWalle, Characterization of soluble organic matter in leachate, Environ. Sci. Technol. 11 (1977) 158-163. 